\title{
Stabilisation of desert sand with cement kiln dust plus chemical additives in desert road construction
}

\section{R. J. Freer-Hewish}

\section{H. R. Elsdale}

The authors in paragraph 34 of the paper referred to their control mix of sand-cement with 10\% cement content. Such a mix would never be used in actual roadworks in Iran, being subject to unacceptible cracking. Frosts are not generally a problem in Iran, and dune sand might be stabilised with 6\% cement for roadworks, rather than $10 \%$ for academic comparisons.

Where dune sand is available in Iran, it would not be necessary to transport more than $6 \%$ cement or other stabilising additives.

Messrs Khansaheb Civil Engineering Contractors used 6\% sulphate-resisting cement successfully in 1968 and 1969 in Sharjah town roads under the supervision of Sir William Halcrow and partner (see Table 3).

Due sand was stabilised with 6\% sulphate-resisting cement in a central plant and placed by tipper better timber shutters

(3.67 m wide bay). It was placed and compacted high, at or above optimum $\mathrm{m} / \mathrm{c}(12 \%)$ and screeded off to within $6 \mathrm{~mm}$. Compaction was entirely by rubber-tyred rollers to 95\% Mod. AASHO density. Curing was by water spray for a few days. Traffic was kept off until the surfacing had been laid. Cracking was negligible except at construction joints. Table 4 gives a summary of the relevant data.

MCO tack coat was applied to the sand-cement. Bitumen macadam was open-textured to BS $1621^{1}$ and used $19 \mathrm{~mm}$ wadi gravel from the Dhaid area. In situ flush concrete kerbs $150 \mathrm{~mm}$ wide and $100 \mathrm{~mm}$ deep were used with $1.5 \mathrm{~m}$ wide subkha shoulders with a 1 in 30 slope. Much later the roads were resurfaced and provided with raised kerbs and footpaths.

Selected locally available subkha was used as a subbase and working platform beneath the sand cement. Subkha is a salty-silty-sand which occurs in salt flats

\begin{tabular}{|ll|}
\hline Description & Constituents \\
\hline Type A & $38 \mathrm{~mm}$ bitumen macadam \\
& $150 \mathrm{~mm}$ sand-cement \\
& 150 or $300 \mathrm{~mm}$ subkha \\
Type B & $63 \mathrm{~mm}$ bitumen macadam \\
& $150 \mathrm{~mm}$ sand-cement \\
& 150 or $300 \mathrm{~mm}$ subkha \\
& \\
\hline
\end{tabular}

fringing tidal salt water lagoons. Subkha can occur in relatively small deposits where it is variable, or in vast areas where each stratum is uniform in quality. At any one location different strata may have different gradings and widely different amounts of shell fragments, silt and salts. Evaporation of the salt groundwater, usually within $0.5 \mathrm{~m}$ of the ground surface, leaves concentrations of salts, particularly of chlorides but also of sulphates and other salts. Undisturbed except for careful compaction, subkha can provide a surfacing akin to asphalt, and excellent temporary working platforms or subbase. Prolonged inundation can destroy the binding effect of its salts and make it unsuitable for roadbase use.

The data presented by the authors might have been more useful to materials engineers if they had adopted three other control mixes; for instance, sand-cement with $6 \%$ cement rather than $10 \%$ cement for their main control mix, as $6 \%$ cement would be durable in most of Iran as a roadbase or sub-base. Sandcement mixes with 10\% cement would be subject to severe 
cracking but would be suitable for sub-base use if covered by at least $100 \mathrm{~mm}$ of granular roadbase or open-graded bitumen macadam to prevent the cracks reflecting up to the road surfacing.

The Cement and Concrete Association used to recommend that seven-day cylinder strengths of 150 psi were ideal for roadbase quality where frosts were unlikely. Seven-day cylinder strengths of 350 psi would make sand-cement immune to damage by frost but susceptible to severe cracking.

If the transport and stabilisation of cement kiln dust (CKD) is barely economic in comparison with sand-cement stabilisation using 40-year-old technology, disposal may be possible using the more modern Thermopave or foamed asphalt technology, which might have provided second and third control mixes.

Where dune sand is not available, granular subgrades can be stabilised with bitumen and sulphur using Thermopave as developed in Canada and all types of sand. It contains 12\% sulphur and 6\% bitumen and is very fluid, needing side shutters until it sets hard like concrete as the sulphur recrystallises, without and compaction being necessary.

Silty subgrades or contaminated pavements can be stabilised effectively by rotovator with hot bitumen and water. Such foamed asphalt might use $4 \%$ bitumen to coagulate and neutralise the finer particles generally but might need much more bitumen to coagulate CKD.

This discussion is intended to encourage the authors to make extra tests of CKD with foamed asphalt, as a means of disposing economically of surplus CKD in roadworks.

\section{Author's reply}

The authors note the lower percentage of cement used in practice. Ten percent had been chosen for the control mix from a disciminatory analysis of reasonable strength gains at seven days, and to compare with other research work.

The purpose of the research was to use by-product/waste material as well as reduce use of conventional binders. In fact, the values achieved by the mixes mentioned by Mr Elsdale have been achieved in the research with partial substitution of conventional binders by waste product additives.

It is interesting to note the use of foam bitumen in the 1960s; it was also being used in Western Australia in the early 1970s. Where did 'foam bitumen' go until recently?

\section{REFERENCE}

1. BRITISH STANDARDS INSTITUTION. BSI, London, 1998, BS1621. 